subjects as credit and money. After he had exhausted the resources of dealers without success, a lucky chance led to his finding his prize in an unusual way. It so happened that his chauffeur had a relative in London, a Mr. Charles Hayden, who delighted in searching for odd and rare items of any description. At Dr. Calvert's request $\mathrm{Mr}$. Hayden started out to explore the manorial estates and private libraries of England and Scotland, which have remained intact in families for hundreds of years. By months of search and thousands of inquiries he managed to trace down two long runs of the Economist to the shelves where the current numbers had been laid aside after the owner had finished his perusal of the latest financial developments, from 1847 on. One of these runs came to the Library.

There is practically no other source of information for some current economic problems as excellent as these London Economists. For example, there is a definite trend in this country toward the establishment of Investment Trusts. Now, to study this it is necessary to have an historical analogy, and in no other records of which we know, is there the material for such a study. The London Economist offers a complete history of such trusts in England. Information of this kind has been used by students like Edgar L. Smith, who recently published an article on "Common Stocks as Long Term Instruments" in the Atlantic Monthly, showing the probable trend of our Investment Trusts in the United States. These particular records are absolutely essential as a background for such studies as his. This is only one among a host of instances in which these old journals, so romantically unearthed from their time-honored hiding-place, will prove invaluable to the historian of business.

\title{
Inn Atemoriam
}

IRWIN KIRKwood, publisher of the Kansas City Star, a member of The Business Historical Society and of its Council, died at Saratoga Springs, New York, on August 29, 1927. He had left his home in Kansas City on August I 5, to attend the races at Saratoga, apparently in excellent health. He was stricken with a hemorrhage and passed away after three days' illness.

Mr. Kirkwood was born in Baltimore, Maryland, December $3 \circ$, I878, the son of Robert and Caroline (Bradenbaugh) Kirkwood, and was educated in public and private schools of his native city. 
In 1905 he went West and located at Kansas City, Missouri, and entered the real-estate business.

On November 15 , I9IO, he was married to Laura, only daughter of William Rockhill Nelson, founder and proprietor of the Kansas City Star, one of the great newspapers of the country. Upon the death of Mr. Nelson in 1915, Mr. Kirkwood became editor and general director of the Kansas City Star and of its morning edition, the Kansas City Times. In February, 1926, Mrs. Kirkwood died, and under the terms of her father's will the newspaper properties were sold, and were bought for $\$ 11,000,000$ by a group headed by Mr. Kirkwood and the general manager of the properties.

Ever since his residence in the west, Mr. Kirkwood had taken an active interest in civic matters, not only of the city, but of the State and the Southwest, and he was recognized in that section as one of the leaders in public affairs. Recently he had been elected a director of the Associated Press.

His death caused profound sorrow over a wide area. The Business Historical Society loses in Mr. Kirkwood one of its early members, and, in common with the many other circles in which he is mourned, feels the loss of his coöperation and interest with deepest regret.

\section{Secretary's Column}

GRATEFUL acknowledgment is made of historical material received during the past month from the following:

Thomas W. Martin, President, Southeastern Power and Light Company, New York.

Richard W. Hale, Hale and Dorr, Boston.

Samuel Powel, Lonsdale Company, Providence.

Wyman K. Flint, Antrim, New Hampshire.

T. A. Kay, Managing Director, The Railway Magazine, London.

The Chairman of the Board of Trade and Industries, Union of South Africa, Pretoria.

The material involved consists of several old account books; "Prices Current" on textile products dated about I 830 ; interesting monographs on the "Inns of the Middle Ages," by W. C. Firebaugh, the "Art of Rigging," by Captain George Biddlecomb, and "Ship Models," by Charles G. Davis; original copies of Land Grants 